\title{
Groundwater Flow Assessment Using Modflow 6 and Model Muse: Application to Pointe-Noire Coastal Aquifers, Congo-Brazzaville
}

\author{
Cordy Jourvel Itoua-Tsele ${ }^{1 *}$, Christian Tathy ${ }^{2}$, David Mumo Malonza ${ }^{3}$ \\ ${ }^{1}$ Department of Mathematics, Pan African University Institute for Basic Science Technology and Innovation, Nairobi, Kenya \\ ${ }^{2}$ LMEI/CUSI/Ecole Nationale Supérieure Polytechnique, Marien Ngouabi University, Brazzaville, Congo \\ ${ }^{3}$ Department of Mathematics, Kenyatta University, Nairobi, Kenya \\ Email: *cordy2018@yahoo.com
}

How to cite this paper: Itoua-Tsele, C.J. Tathy, C. and David Malonza, M. (2021) Groundwater Flow Assessment Using Modflow 6 and Model Muse: Application to Pointe-Noire Coastal Aquifers, Congo-Brazzaville. Journal of Water Resource and Protection, 13, 900-914.

https://doi.org/10.4236/jwarp.2021.1311048

Received: June 23, 2021

Accepted: November 27, 2021

Published: November 30, 2021

Copyright $\odot 2021$ by author(s) and Scientific Research Publishing Inc. This work is licensed under the Creative Commons Attribution International License (CC BY 4.0).

http://creativecommons.org/licenses/by/4.0/

\begin{abstract}
As numerical modeling is an effective tool for managing groundwater resources and predicting future responses, in this study, the author has intended to assess groundwater flow through Modflow 6 and Model Muse into Pointe-Noire coastal aquifers. The results showed that the fourth scenario has the biggest effect on the drawdown and seawater intrusion extent. Different parameters including evapotranspiration, recharge, model boundary, etc. were adjusted to run the model. The fourth scenario with the highest pumping rate value caused a slight increase of head values over the values simulated.
\end{abstract}

\section{Keywords}

Groundwater, Pointe-Noire, Coastal Aquifers, Modflow, Model Muse

\section{Introduction}

The coastal aquifers of Pointe-Noire is a highly strategic area for daily needs of households and industrial; and the population depends on it and due to the proliferation of boreholes is a threat to the groundwater in Pointe-Noire, excessive pumping increases the risk of intrusion and the degradation of water quality, with decreases in piezometric levels since the pumping rate in coastal aquifers is higher than the intake and storage contribution, seawater is introduced into the aquifer and interacts with existing wells [1] [2] [3] [4].

In this paper, we are interested to model the risk of seawater intrusion in Pointe-Noire coastal aquifers by showing the impact of intense exploitation of 14 
high-performance wells over a 10, 15, 20 and 25-year simulation using Modflow 6 and Model Muse, which is a modeling software developed by the USGS and coupled on MODFLOW-2005 [5].

The study area that is the subject of this study suffers from a lack of data researchers, several studies were conducted by researchers from the Republic of Congo, all data resulting from these researchers [1] [2] [3] [4] [6] [7].

\section{Description of the Study Area (Figure $1 \&$ Figure 2)}

The Pointe-Noire coastal aquifer system extends the south-western of CongoBrazzaville along Atlantic coast in Central Africa and its DMS coordinates

\section{Kouilou Department}

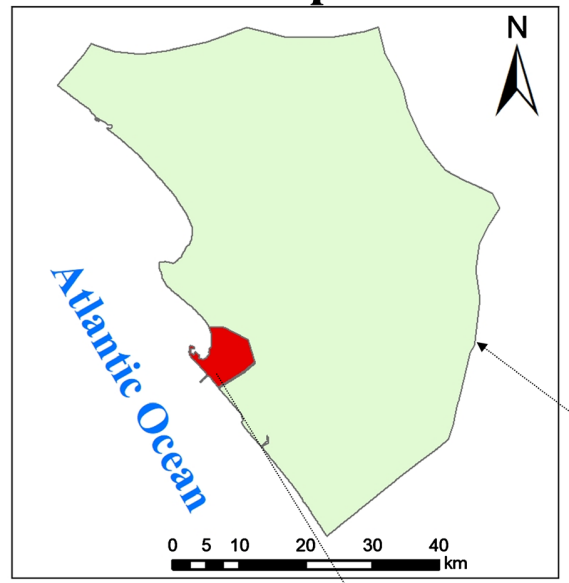

\section{Republic of Congo}

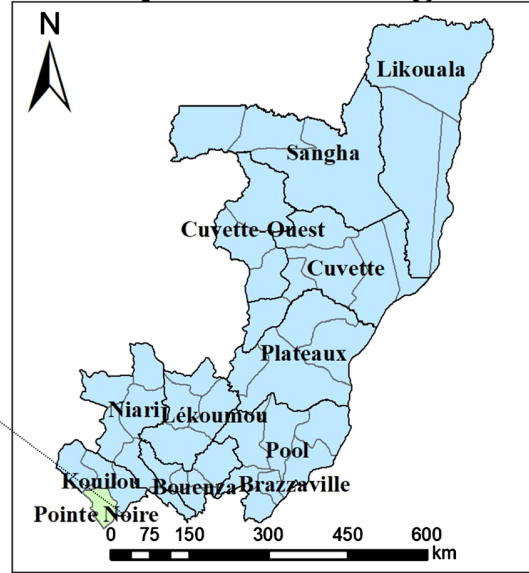

\section{Point Noire}

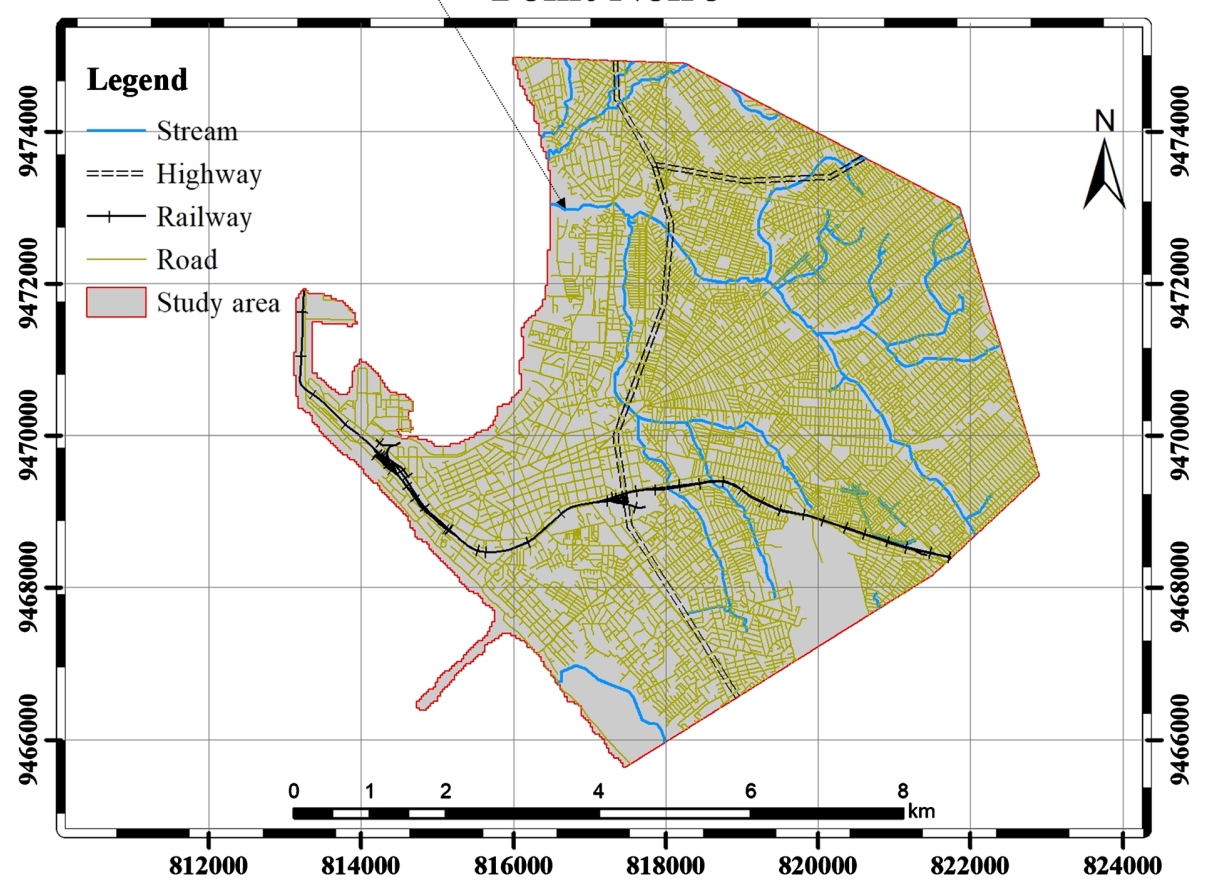

Figure 1. Location of the study are. 


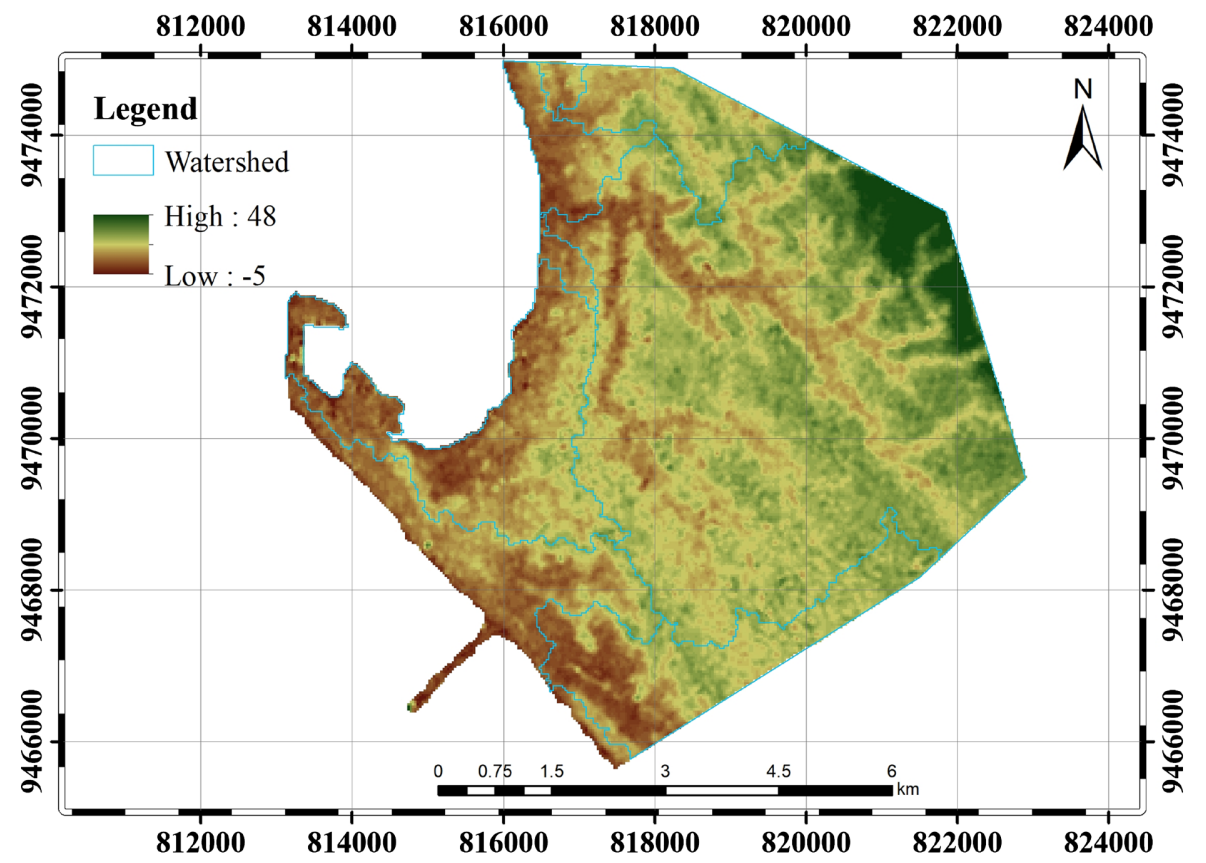

Figure 2. Topographic map symbolizes relief and contour lines.

are $4^{\circ} 46^{\prime} 43^{\prime \prime} \mathrm{S}$ and $11^{\circ} 51^{\prime} 49^{\prime \prime} \mathrm{E}$, it is bounded to the southwest by the Atlantic Ocean, north-west by the border of the Republic of Gabon, southeast by the Angolan enclave of Cabinda and northeast of the mountain Mayombe, it occupies an area of approximatively $6000 \mathrm{~km}^{2}$ and has a population about 715,334 million inhabitants in 2007, expanding to well over 1 million when the entire metropolitan area is taken into account; with a mean soil elevation of $14 \mathrm{~m}$ above sea level and which is divided into six districts. The climate of the study area is tropical savanna climate under the Köppen climate classification, and the annual precipitations are relatively moderate on average $1200 \mathrm{~mm}$ compared to the entire country, temperatures range between $22.2^{\circ}$ and $28^{\circ}$ [8] [9] [10]. The total water for Pointe-Noire demand was estimated to be $50,000 \mathrm{~m}^{3} /$ day of potable water.

\section{Hydrogeologic of the Study Area}

\subsection{Aquifer}

Aquifers (AQ) in Pointe-Noire comes in two types which are confined and unconfined aquifers, the wildly aquifer used is AQ-2 for water requirement. It consists of a hydrogeological complex including an aquifer system of several layers with hydraulic continuity according to geological and its direction of flow. A hydrogeological information system for the AQ-2 aquifer has been developed from a historical reconstruction of piezometric boreholes and piezometers from different measurement companions carried out using geographic information systems [1] [8] [11]. These aquifers are geologically characterized by their lithology or rock type, which can be successively determined as follows [1] [6]:

- The unconfined aquifer AQ-1 contains a free water table, corresponding to the saturated medium of the most permeable and draining layers of the surface 
sands; of variable thickness which is on average from $14 \mathrm{~m}$ to Pointe Noire and the recharge of this aquifer is done by infiltration of rainwater estimated to 350 $\mathrm{mm} /$ year [7] and the discharge takes place via streams and sources, by flowing towards the ocean [12];

- the confined aquifer AQ-2 contains a deep confined artesian or flowing well, in certain places, corresponding to the most permeable layers of the series of circuses (quaternary). This AQ-2 aquifer has an average thickness of 20 to 30 $\mathrm{m}$ and a depth between 80 and $180 \mathrm{~m}$, consists of heterogeneous sands, silt sometimes alternating with levels argillit;

- the aquifer AQ-3 (confined), contains a confined aquifer corresponding to the most permeable layers of iron sands, sands sometimes composed of heterogeneous conglomerates alternating with ferruginous concretions;

- the aquifer AQ-4 (confined) also contains a confined aquifer, based on a low permeability substrate and bounded by a low permeability super-stratum, corresponding to the less permeable strata of the gresco-dolomitic series (secondary), consists of clay sands and dolomitic aggregates;

- the potential aquifer AQ-5, is a so-called potential aquifer corresponding to the unit of dolomite and calcite of the calcaro-dolomitic series in which circulation losses have been observed in certain mineral exploration wells.

The configuration of the aquifers of the coastal sedimentary basin is presented in Figure 3.

The previous geological studies made in this region [1] [3] [4] [6] [7], made it possible to define in detail the structure of the different aquifers horizons, Figure 4 shows the aquifer surfaces in Pointe-Noire region, the first layer contains shallower aquifers AQ-1, and its upper surface represents the topography of the study area, the second in pink color is essentially the impermeable layer, it does not containt whater, and the third layer represents the main aquifers AQ-2 which are saturated with water, where the wells are located in green. Table 1 shows the lithostratigraphy and hydrostratigraphy of the Pointe-Noire Coastal aquifers

\subsection{Hydrodynamic Characteristics}

The hydrogeological characteristics of the aquifer system in the Pointe-Noire
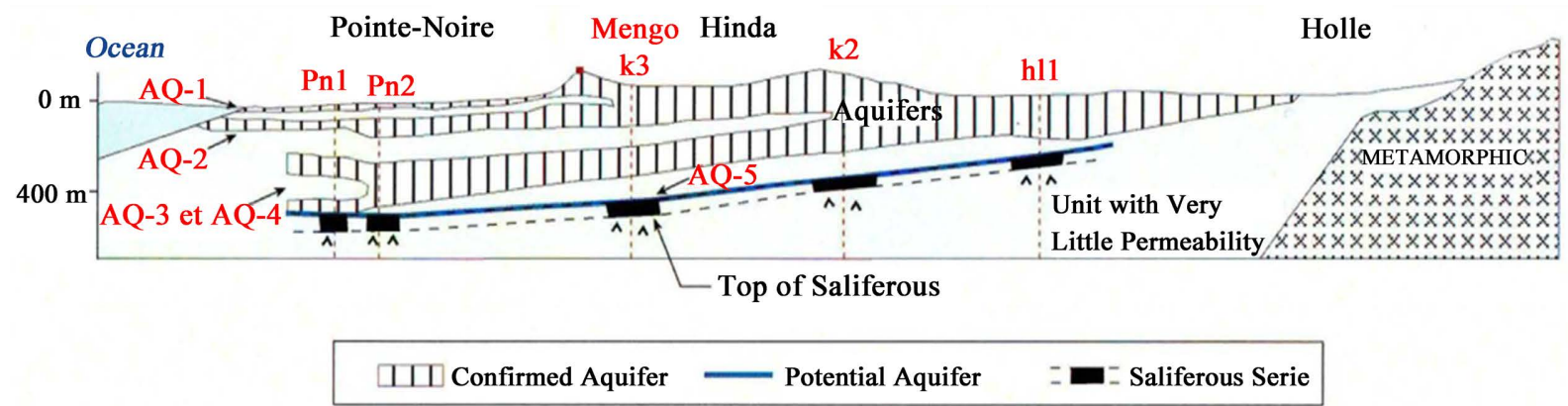

$$
\begin{array}{lll}
0 & 2 & 4 \mathrm{~km}
\end{array}
$$

Figure 3. Cross section of the multi-layer aquiferous system of Pointe-Noire [1] [6]. 


\begin{tabular}{|l|}
\hline \multicolumn{1}{|l|}{ Legend } \\
Wells \\
Streams \\
DEM. tif \\
Value (m) \\
High: 80 \\
Low: 1 \\
Confining unit 1 \\
Value (m) \\
High: 185.736 \\
Low: 115.25 \\
Confining unit 2 \\
Value (m) \\
High: 119.535 \\
Low: 46.1469
\end{tabular}

Figure 4. Aquifers visualization of Pointe-Noire.

Table 1. Lithostratigraphy and Hydrostratigraphy of the Pointe-Noire Coastal aquifers [5].

\begin{tabular}{|c|c|c|c|c|c|c|}
\hline \multicolumn{3}{|c|}{ Geologic Units } & \multirow{2}{*}{$\begin{array}{l}\text { Hydrogeologic } \\
\text { Units }\end{array}$} & \multirow[t]{2}{*}{ Nomenclature SPC } & \multirow{2}{*}{$\begin{array}{l}\text { Thickness } \\
\text { range, in } \\
\text { meter }\end{array}$} & \multirow{2}{*}{$\begin{array}{l}\text { Model } \\
\text { layer }\end{array}$} \\
\hline System & Series & Formation & & & & \\
\hline \multirow[t]{5}{*}{ Tertiary } & \multirow{5}{*}{$\begin{array}{l}\text { Distal } \\
\text { accretion }\end{array}$} & Plio-quaternary & Model Top & Sables & $\sim 0$ or 5 & 1 \\
\hline & & Lower Miocene & \multirow{8}{*}{$\begin{array}{l}\text { Upper aquifer } \\
\text { (Unconfined) }\end{array}$} & \multirow[t]{10}{*}{ Coarse sand ferruginous series } & 5 to 21 & \\
\hline & & Aquitanian & & & 21 to 43 & \\
\hline & & Oligocene & & & & \\
\hline & & Eocene-Paleocene & & & 43 to 65 & \\
\hline \multirow[t]{15}{*}{ Quaternary } & \multirow{8}{*}{$\begin{array}{l}\text { Proximal } \\
\text { accretion }\end{array}$} & Maestrichtian & & & 65 to 83 & \\
\hline & & Senomien Campanian & & & & \\
\hline & & Santonian & & & & \\
\hline & & Coniacien & & & 83 to 94 & \\
\hline & & Turonian & & & & \\
\hline & & Cenomanian & & & 94 to 100 & \\
\hline & & Albian & Transition & Clay-gresco-dolomitic series & 100 to 106 & Impervious \\
\hline & & & $\begin{array}{l}\text { Upper and lower } \\
\text { confining units }\end{array}$ & Dolomitic calcaro series & & \\
\hline & \multirow{3}{*}{$\begin{array}{l}\text { Lagoon } \\
\text { evaporitic }\end{array}$} & Aptian & (Not simulated) & Anhydritic series & 106 to 113 & \\
\hline & & & & Salifere & & \\
\hline & & & & Chela & & \\
\hline & \multirow{4}{*}{$\begin{array}{l}\text { Limnic } \\
\text { lacustrine }\end{array}$} & Neocomian & \multirow{3}{*}{$\begin{array}{l}\text { Lower aquifer } \\
\text { (Convertible) }\end{array}$} & \multirow{3}{*}{$\begin{array}{l}\text { Infrasalifere series } \\
\text { Series of arkoses and } \\
\text { psammites at the edge of the } \\
\text { base }\end{array}$} & 113 to 118 & 2 \\
\hline & & Barremian & & & & \\
\hline & & Neocomian & & & 118 to 131 & \\
\hline & & & Base of model & & & \\
\hline
\end{tabular}


region influence the recharge and exploitation conditions which induce particular problems to be taken into account during modeling. The overexploitation of water resources in this region leads to a vulnerability of the aquifers of this system to the seawater intrusion from the ocean. This limits the potential of the resource and can generate huge investments to ensure its use [1] [4]. In this study, hydrogeological, geophysical, and geochemical data used to simulate the flow were obtained from in-situ experiments carried out by technicians from the ministry of hydraulics [2] [3] [4] and others researchers [1] [7] [8].

Hydraulic parameters (transmissivity and storage coefficient) data are rare; they come from long-term pumping tests carried out as part of study [2]. The transmissivity values $(\mathrm{T})$ of the water table in Pointe-Noire region vary from $10^{-2}$ to $10^{-3} \mathrm{~m} / \mathrm{s}$ and that of the storage coefficient (S) between $10^{-4}$ and $10^{-5}$. The values of $\mathrm{T}$ reported in the average thickness of 20 to $30 \mathrm{~m}$ of the aquifer AQ-2 give values of hydraulic conductivity $(\mathrm{K})$ of the order of $10^{-4}$ to $10^{-5} \mathrm{~m} / \mathrm{s}$.

\subsection{Groundwater Piezometric}

Thanks to the work carried out by the Ministry of Hydraulics, we consider the piezometry of 2012 [3] that we georeferenced it using software ArcGIS 10.5.

A monthly monitoring over a hydrological year was carried out at the level of the piezometric network and of some cartesian wells located in certain districts of Pointe-Noire [3], shows the groundwater flow towards the Southwest.

\section{Model Development Procedure}

\subsection{Modeling of Fluid Flow}

In this section, we present a state of current knowledge of the data for the numerical model in particular: the geometry of the domain (shape of the model area, elevation of the bottom and top of the aquifer, thickness of the aquifer); aquifer parameters (Distribution of hydraulic conductivity $(\mathrm{K})$, transmissivity $(\mathrm{T})$, storage coefficient (S), etc.); Inputs (the location of the pumping wells, discharge/well recharge, recharge groundwater by precipitation water, field flow boundary, potential evapotranspiration, ...).

\subsubsection{Aquifer Geometry}

The aquifer is bounded on the west by the ocean, to the east by Hinda made up of Quaternary sedimentary deposits based incoherently on impermeable facies, northwest and southeast boundaries are tight due to the flow direction which is perpendicular to the axes of hydraulic Kouilou and Loémé.

\subsubsection{Boundary Conditions}

MODFLOW 6 is the newest version of MODFLOW and MODEL MUSE is a graphical user interface (GUI) for U.S. Geological Survey (USGS) models MODFLOW 6, MODFLOW-2005, MODFLOW-LGR, MODFLOW-LGR2, MODFLOW-NWT, MODFLOW-CFP, MODFLOW-OWHM, MODPATH, ZONEBUDGET, PHAST, 
SUTRA 2.2, SUTRA 3.0, MT3D-USGS, and Well Footprint and the non-USGS model MT3DMS [13]. The main physical process related to the modeling of groundwater system in Pointe-Noire coastal aquifers is complex with main focus on:

- Recharge one of the difficult parameters to evaluate mostly on confined aquifer case, Darcy velocity approach has been used to obtain the flow rate of the aquifer which come out of the downstream outlet (ocean) to the distance between Djéno and Mandingo Kayes and has a thickness of 20 to $30 \mathrm{~m}$; thus, an average value of $6.5 \times 10^{-4} \mathrm{~m} / \mathrm{d}(237 \mathrm{~mm} /$ year, representing $20 \%$ of the average rainfall) [3];

- Pumping well exploitation discharge and interaction with seawater, the AQ-2 aquifer is heavily exploited in the city of Pointe Noire; the flow rates range from minus $5 \mathrm{~m}^{3} / \mathrm{h}$ to $100 \mathrm{~m}^{3} / \mathrm{h}$ depending on use and the depths of the works. The highest rates are from deeper wells, particularly those managed by La Congolaise Des Eaux (LCDE), the company of water supply, are the most exploited. The total flow rates operated by LCDE from 23 wells located in the city of Pointe Noire vary on average from 42,000 to $50,000 \mathrm{~m}^{3} / \mathrm{j}$ during the period of 2009 to 2010 [2]. Wells considered to study groundwater into the AQ- 2 of Pointe-Noire are shown in Table 2 below;

- River simulation of river interaction with the aquifer, the conductance per unit length or area is $3 \mathrm{E}-6$ and the elevation is the model top;

- Evapotranspiration in zones with water table close to surface, several calculation methods have been developed to estimate evapotranspiration and for

Table 2. Wells considered to study groundwater into the AQ-2 of Pointe-Noire.

\begin{tabular}{|c|c|c|c|c|c|c|c|c|c|}
\hline ID & Location name & Latitude & Longitude & $\begin{array}{l}\text { Elevation } \\
\text { (m) }\end{array}$ & $\begin{array}{l}\text { Bottom of } \\
\text { aquifer }(\mathrm{m})\end{array}$ & $\begin{array}{c}\text { Top of } \\
\text { aquifer }(\mathrm{m})\end{array}$ & $\begin{array}{l}\text { Initial } \\
\text { time(s) }\end{array}$ & $\begin{array}{c}\text { Final } \\
\text { time (s) }\end{array}$ & $\begin{array}{l}\text { Pumping } \\
\text { rate }\left(\mathrm{m}^{3} / \mathrm{h}\right)\end{array}$ \\
\hline $\mathrm{PZ1}$ & Tchiali & $4^{\circ} 44^{\prime} 11^{\prime \prime}$ & $11^{\circ} 52^{\prime} 31^{\prime \prime}$ & 24.55 & 119 & 22.22 & 0 & $788,940,000$ & -5 \\
\hline $\mathrm{PZ2}$ & CORAF & $4^{\circ} 44^{\prime} 33^{\prime \prime}$ & $11^{\circ} 51^{\prime} 14^{\prime \prime}$ & 10.31 & 102 & 11.98 & 0 & $788,940,000$ & -5 \\
\hline PZ3 & Songolo & $4^{\circ} 45^{\prime} 56^{\prime \prime}$ & $11^{\circ} 51^{\prime} 38^{\prime \prime}$ & 5.05 & 5.054 & 6.6 & 0 & $788,940,000$ & -5 \\
\hline $\mathrm{PZ4}$ & Loandjili & $4^{\circ} 46^{\prime} 02^{\prime \prime}$ & $11^{\circ} 52^{\prime} 13^{\prime \prime}$ & 16.07 & 115 & 9.4 & 0 & $788,940,000$ & -5 \\
\hline PZ6 & Tchibati & $4^{\circ} 46^{\prime} 13^{\prime \prime}$ & $11^{\circ} 54^{\prime} 16^{\prime \prime}$ & 26.76 & 8.189 & 10.73 & 0 & $788,940,000$ & -5 \\
\hline PZ7 & ORSTOM & $4^{\circ} 46^{\prime} 38^{\prime \prime}$ & $11^{\circ} 51^{\prime} 19^{\prime \prime}$ & 6.28 & 1.146 & 5.02 & 0 & $788,940,000$ & -5 \\
\hline PZ8 & Matende & $4^{\circ} 47^{\prime} 03^{\prime \prime}$ & $11^{\circ} 54^{\prime} 22^{\prime \prime}$ & 8.12 & 5.325 & 8.29 & 0 & $788,940,000$ & -5 \\
\hline PZ9 & Mbota Bissongo & $4^{\circ} 47^{\prime} 45^{\prime \prime}$ & $11^{\circ} 54^{\prime} 20^{\prime \prime}$ & 17.42 & 2.313 & 10.13 & 0 & $788,940,000$ & -5 \\
\hline PZ10 & Mvoungou & $4^{\circ} 48^{\prime} 09^{\prime \prime}$ & $11^{\circ} 53^{\prime} 23^{\prime \prime}$ & 11.00 & 4.768 & 2.35 & 0 & $788,940,000$ & -5 \\
\hline PZ11 & Cercle Nautique & $4^{\circ} 49^{\prime} 25^{\prime \prime}$ & $11^{\circ} 54^{\prime} 18^{\prime \prime}$ & 2.75 & 4.28 & 1.65 & 0 & $788,940,000$ & -5 \\
\hline PZ12 & Saint Pierre & $4^{\circ} 44^{\prime} 11^{\prime \prime}$ & $11^{\circ} 52^{\prime} 31^{\prime \prime}$ & 11.78 & 17.456 & 8.68 & 0 & $788,940,000$ & -5 \\
\hline PZ13 & Mboukou & $4^{\circ} 44^{\prime} 33^{\prime \prime}$ & $11^{\circ} 51^{\prime} 14^{\prime \prime}$ & 16.39 & 10.293 & 7.29 & 0 & $788,940,000$ & -5 \\
\hline PZ14 & Mbita Kronnenbourg & $4^{\circ} 45^{\prime} 56^{\prime \prime}$ & $11^{\circ} 51^{\prime} 38^{\prime \prime}$ & 10.39 & 5.054 & 0.15 & 0 & $788,940,000$ & -5 \\
\hline PZ15 & Mpaka & $4^{\circ} 46^{\prime} 02^{\prime \prime}$ & $11^{\circ} 52^{\prime} 13^{\prime \prime}$ & 15.45 & 6.394 & 7.19 & 0 & $788,940,000$ & -5 \\
\hline
\end{tabular}


an average annual rainfall of $1200 \mathrm{~mm}$ in Pointe-Noire, aquifer recharge is estimated at $400 \mathrm{~mm}$ [1] [10];

- General head boundary simulation of the aquifer interaction with the sea, the conductance per unit length or area is 0.002 and the boundary head is zero.

\section{Results and Discussions}

The data processing steps undertaken in this GIS and modeling study are described in some detail above, and a critical assessment is given of the data availability and the requirements for successful monitoring and now we are modeling groundwater to assess the risks in heavily exploited AQ-2 aquifers. Wells are located from layer 3, which is confined. We are looking for the impact of high pumping wells on groundwater exploitations of 14 wells in four suggested scenarios of 10, 15, 20 and 25 years from 2021 by using the three-dimensional finite volume flow model (Modflow 6) to simulate the flow system. These scenarios include: first, model will run under steady-state without good pumpage; second, steady-state solution under pumping taking the solution in the first stage; third, running of the model where the pumping rate is constant for all well during the interval 2021-2046 without any management or climate change effects; and finally, model will run with abstraction for all well and management or climate effects. Discretization of the domain of the study is shown in Figure 5 below.

In scenario 1 , the simulation results by using Model Muse indicate that without pumping well, the hydraulic head varied from 1 to 6 meters, taking into account the drain and recharge packages, under steady state evaluated at 10 years stress period see Figure 6 and Figure 7, 15 years stress period see Figure 8 and Figure 9 and 20-year stress period see Figure 10 and Figure 11, therefore there is no impact in the groundwater level since the wells of the aquifer are not neglected.

Scenario 2 focuses on the impact of fixed pumping rate $-5 \mathrm{~m}^{3} / \mathrm{yr}$ (according to the data available) on groundwater level aquifer without taking account the climate change by using Model Muse. The results of scenario 2 showed that there is

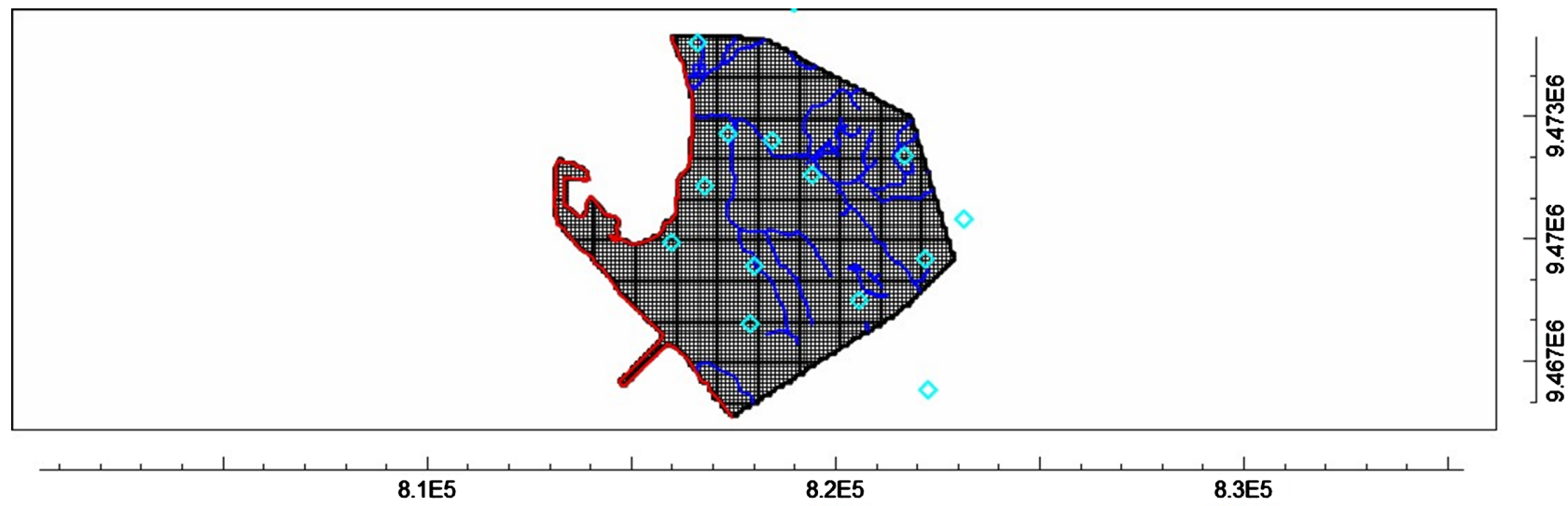

Figure 5. Discretization of the domain of study. 


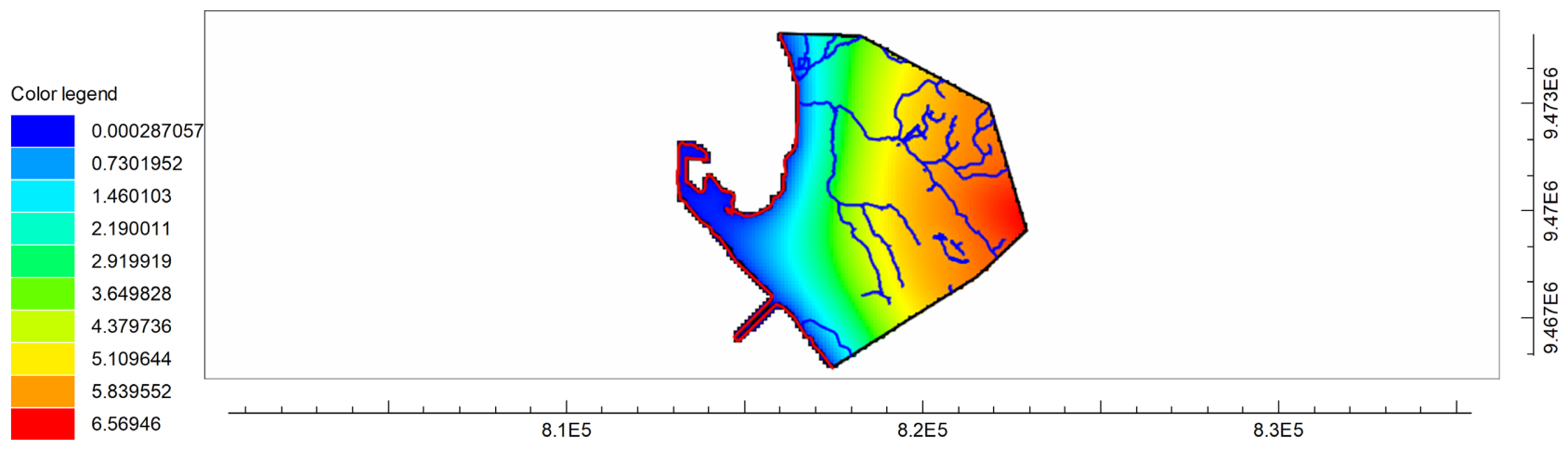

Figure 6. Isosurface of hydraulic head simulated at 10 years without pumping.

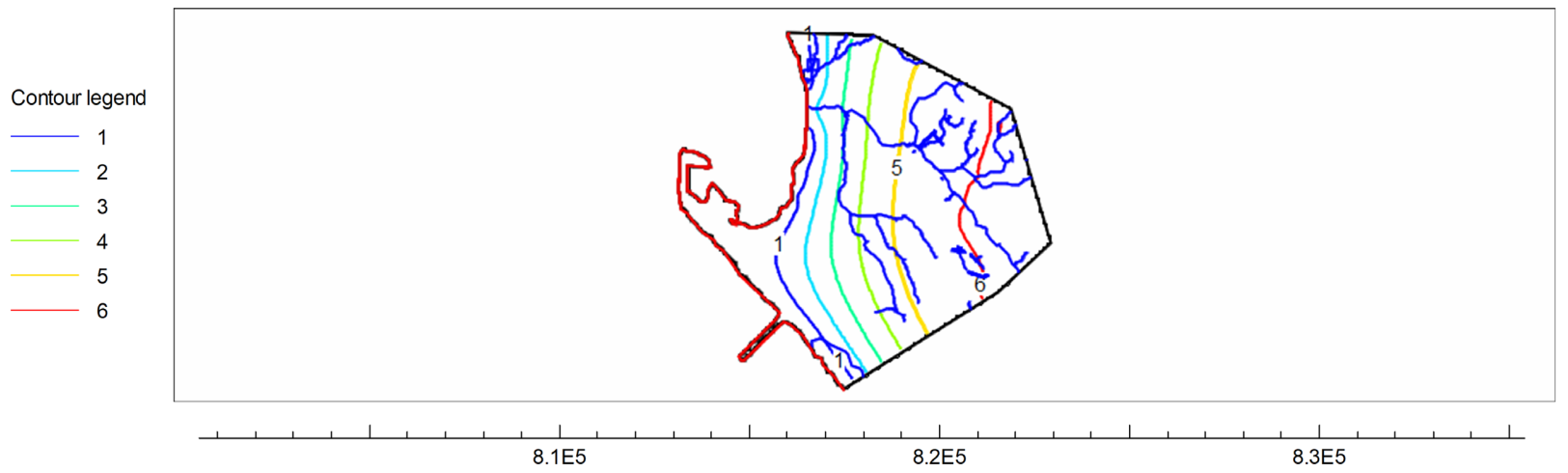

Figure 7. Contour of hydraulic head simulated at 10 years without pumping.

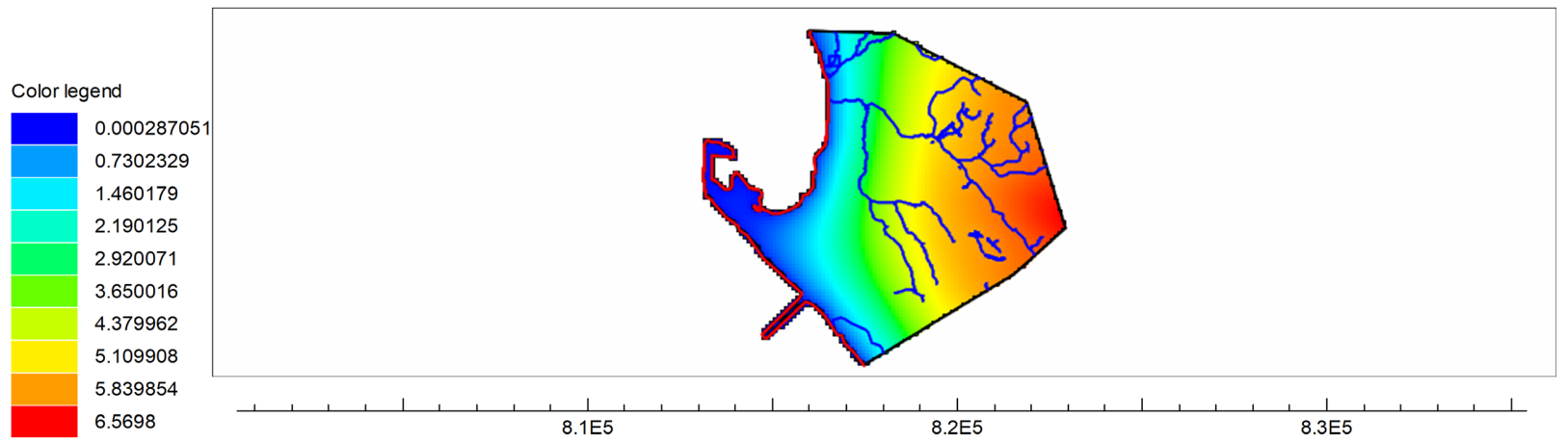

Figure 8. Isosurface of hydraulic head simulated at 15 years without pumping.

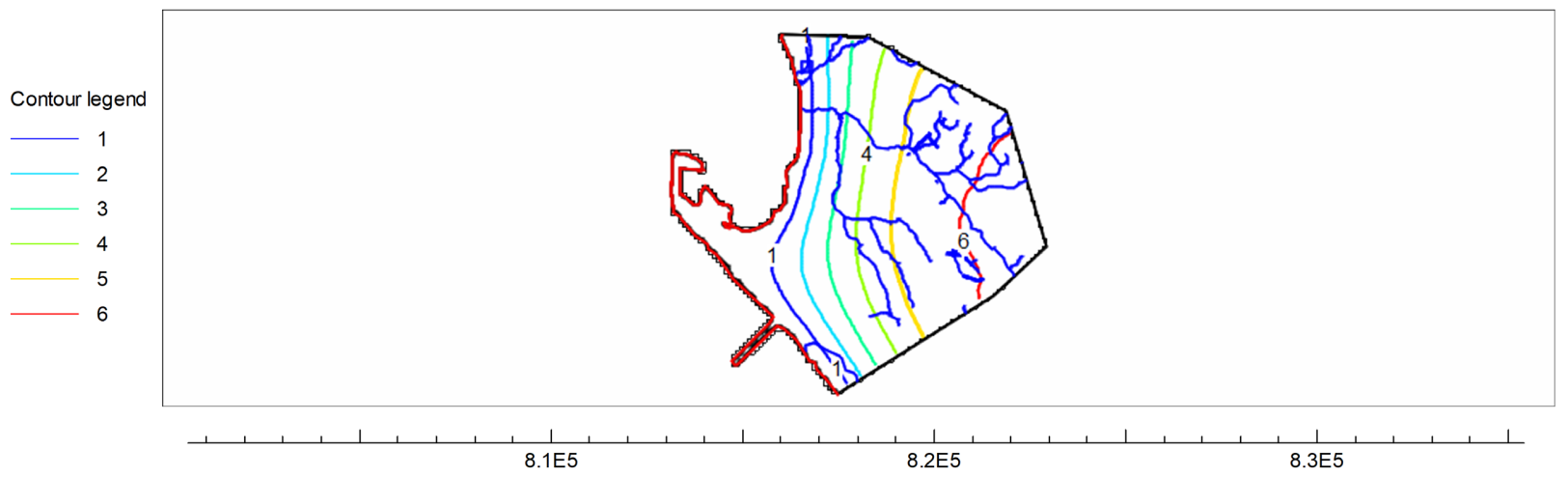

Figure 9. Contour of hydraulic head simulated at 15 years without pumping. 
a continuous decline and a negative effect in the groundwater level in these profiles due to fixed pumping and the selected results are shown in Figure 12 and Figure 13. However, Figure 14 and Figure 15 show that the hydraulic head is a negative constant in stress period 2.

Scenario 3 focuses on the impact of sustainable abstraction rate on groundwater level without considering climate change. Simulation results as shown in Figure 16 and Figure 17 there is a continuous decline and a negative effect in the groundwater level. These are due the fact that there is no impact of climate change. However, Figure 18 and Figure 19 show that the hydraulic head are constant in stress period 2.

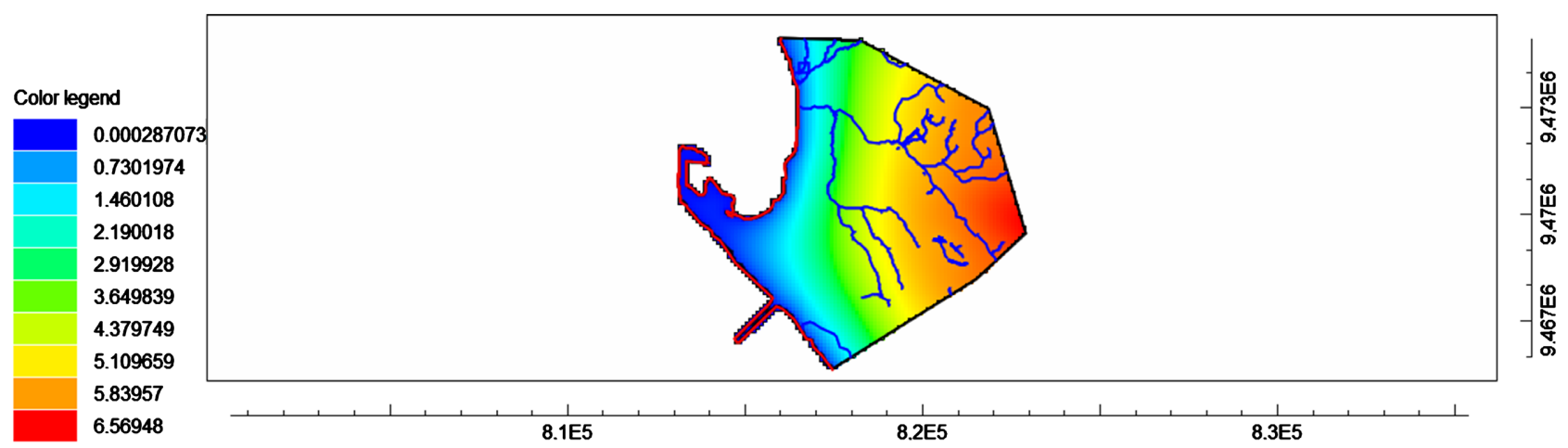

Figure 10. Isosurface of hydraulic head simulated at 20 years without pumping.

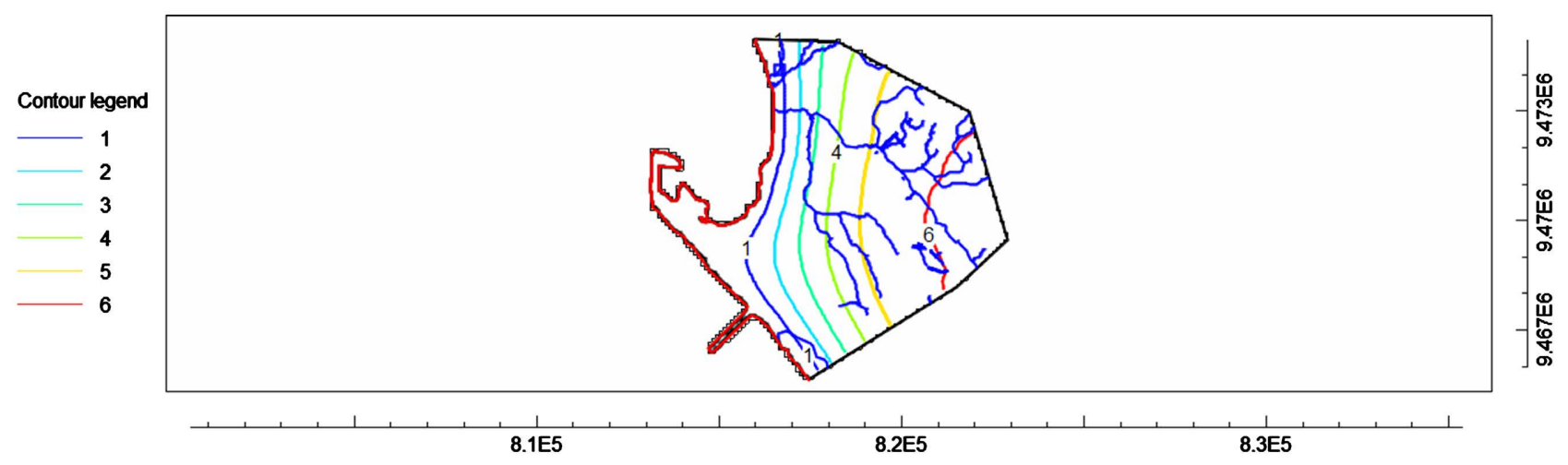

Figure 11. Contour of hydraulic head simulated at 20 years without pumping.

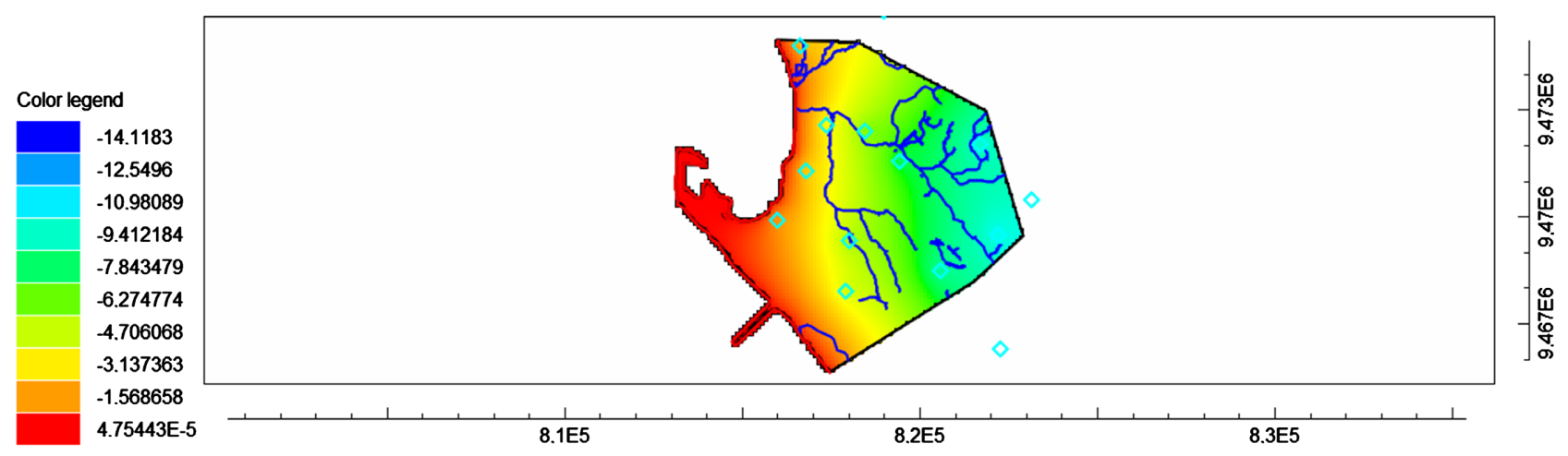

Figure 12. Isosurface of hydraulic head simulated at 10 years with pumping. 


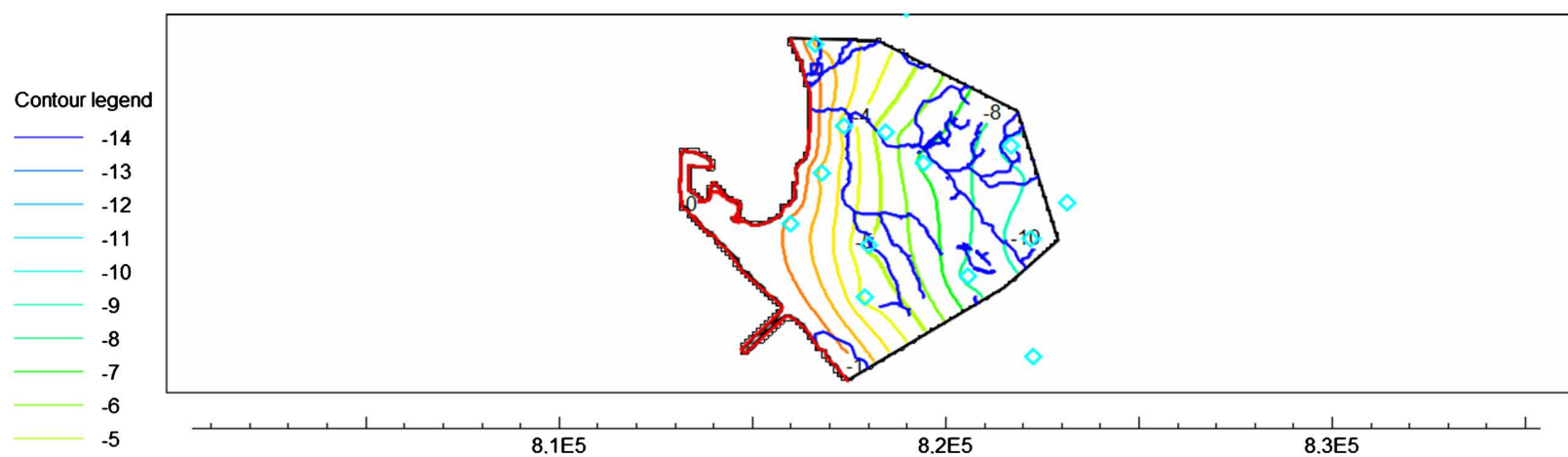

Figure 13. Isosurface of hydraulic head simulated at 10 years with pumping.
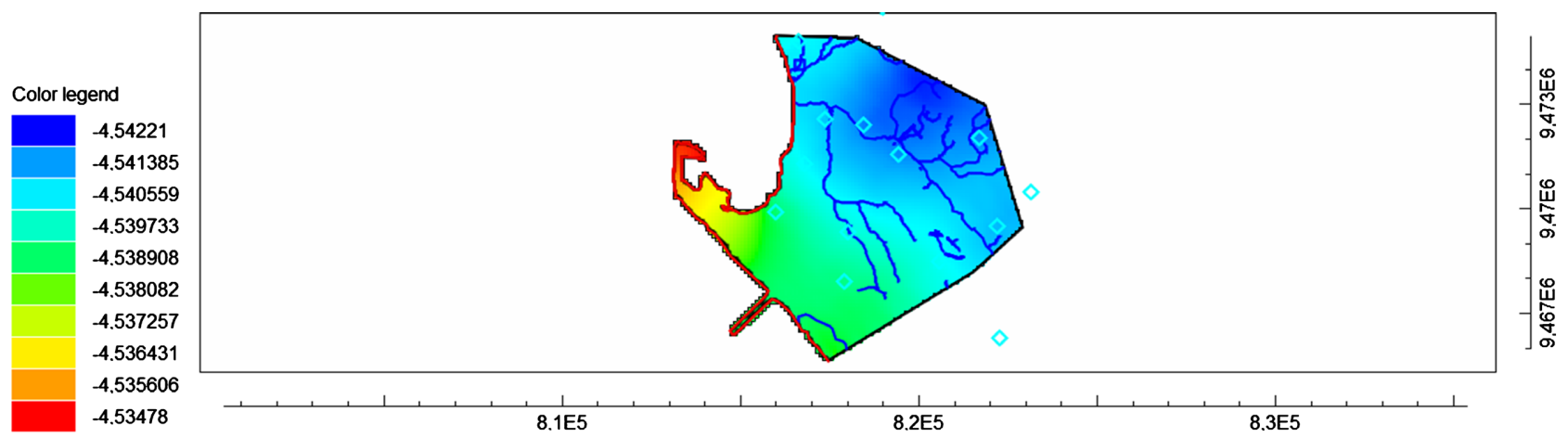

Figure 14. Isosurface of hydraulic head simulated at 25 years with pumping.
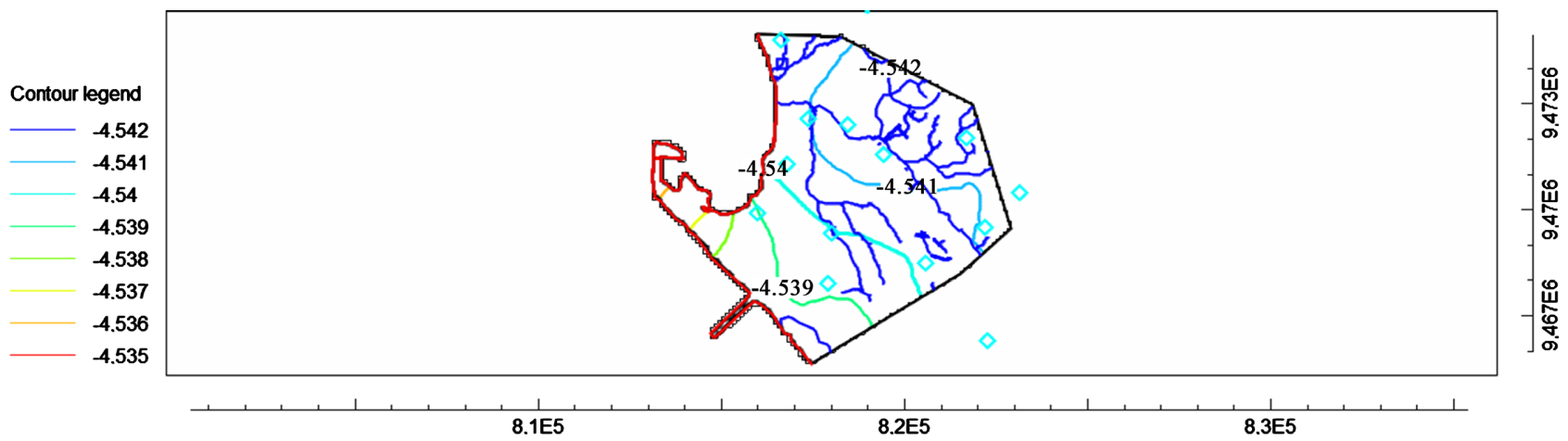

Figure 15. Contour of hydraulic head simulated at 25 years with pumping.

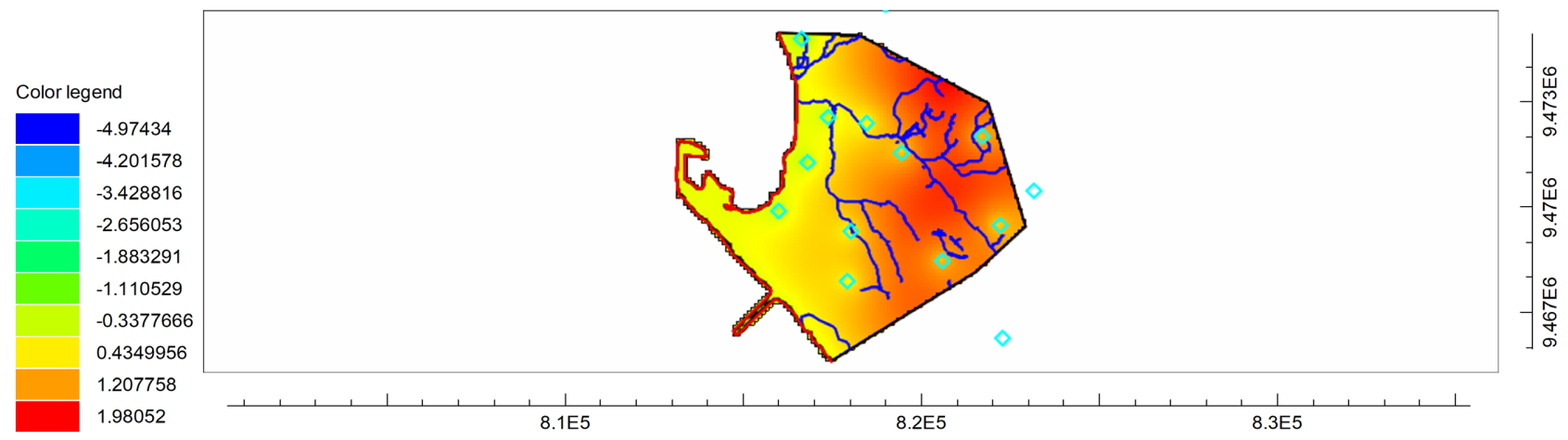

Figure 16. Isosurface of hydraulic head simulated at 10 years with pumping in steady state and without the influence of the climate and others. 


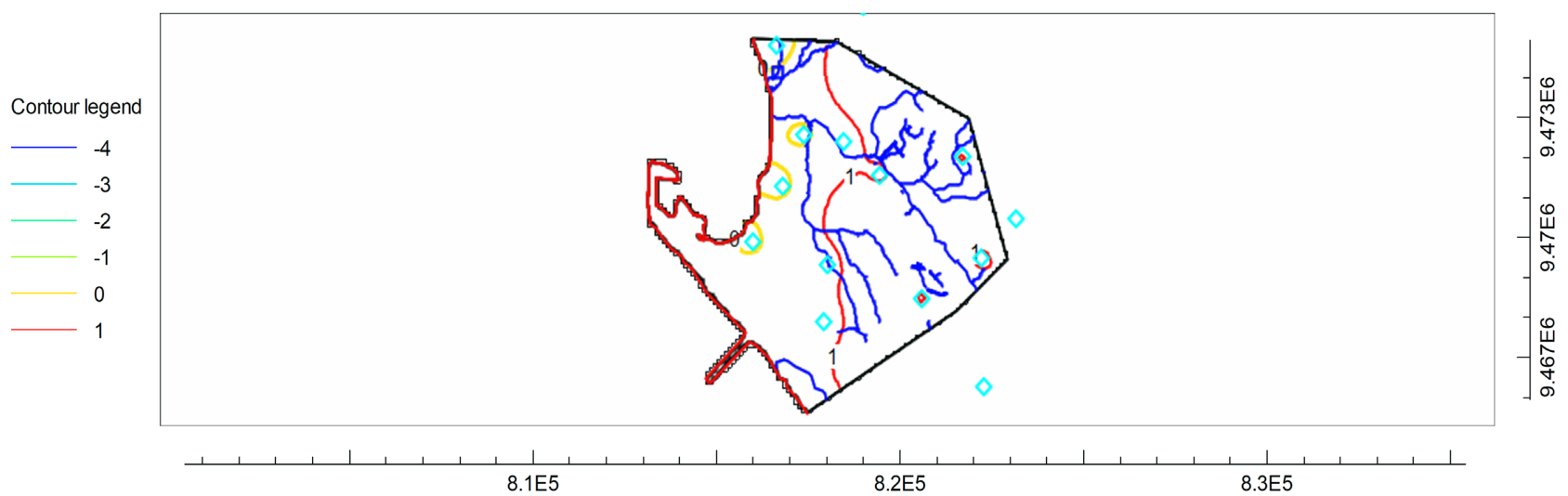

Figure 17. Contour of hydraulic head simulated at 10 years with pumping in steady state and without the influence of the climate and others.

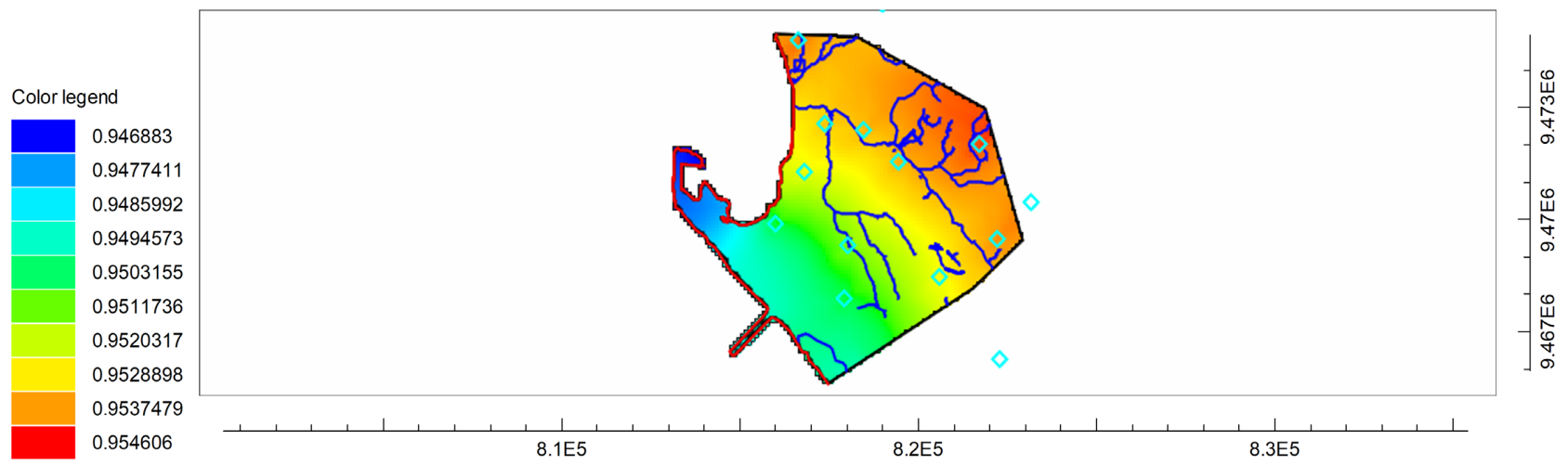

Figure 18. Isosurface of hydraulic head simulated at 25 years with pumping steady state and without considering the climate change and others.

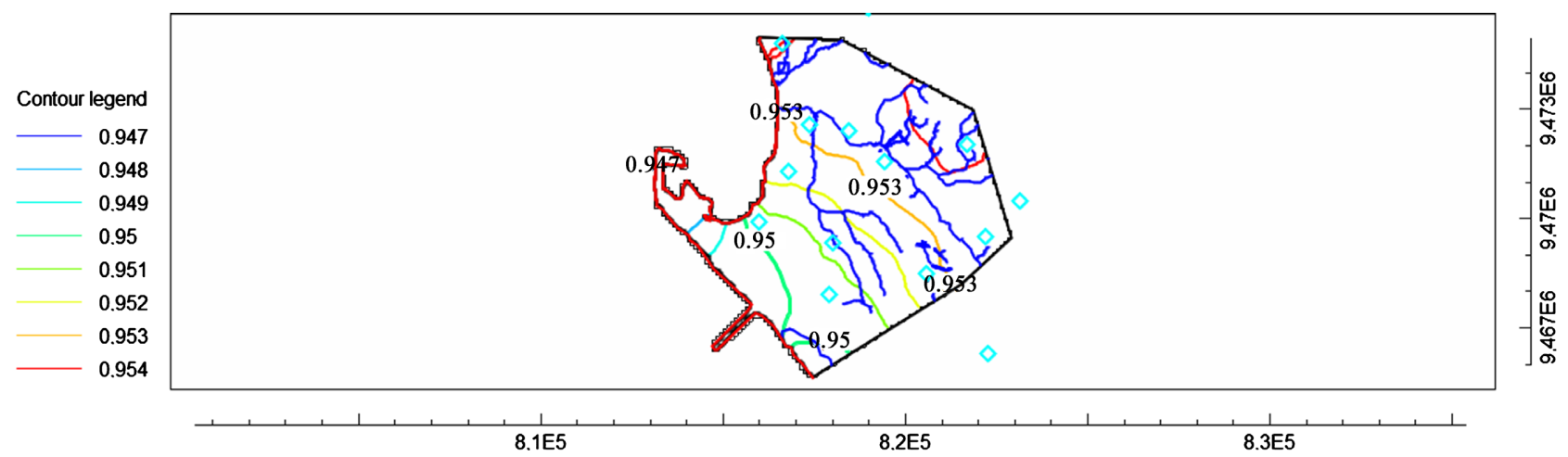

Figure 19. Contour data simulated at 25 years with pumping in steady state and without considering the climate change and others.

Scenario 4 is a case study, where the impact of sustainable abstraction rate on groundwater level taking in consideration climate change, recharge and evapotranspiration. Simulation results as shown in Figure 20 and Figure 21 that the hydraulic head is influenced by changes of the climate such as recharge and evapotranspiration and also Figure 22 and Figure 23 have a clear impact on aquifer AQ-2 where the groundwater levels are constant and this helps to assess the impact of groundwater in Pointe-Noire region. 


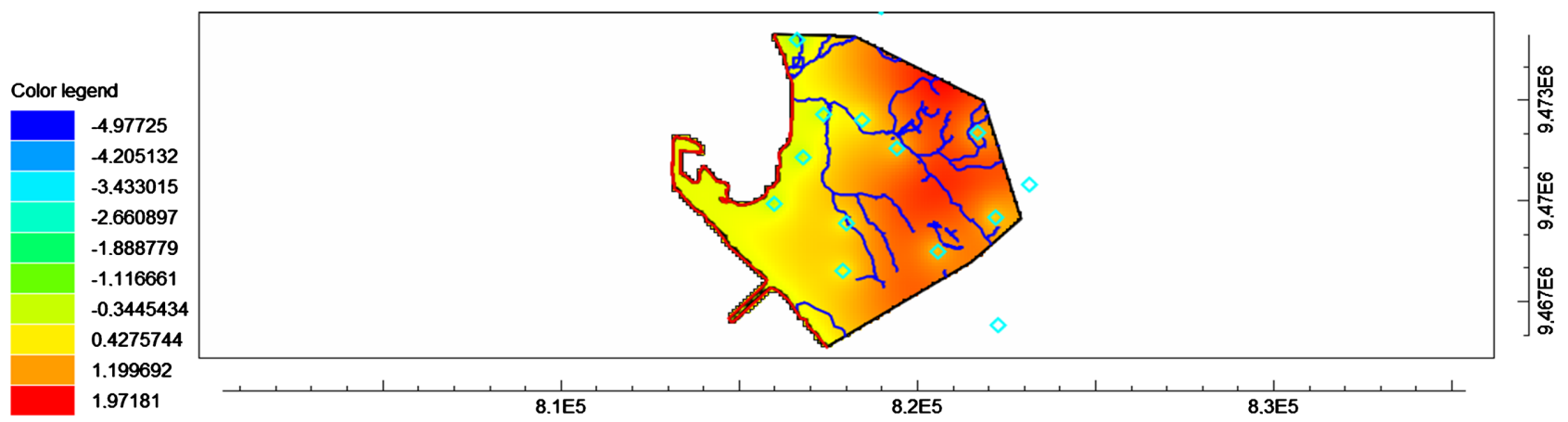

Figure 20. Color grid simulated at 10 years with pumping in steady state and the influence of the climate and others.

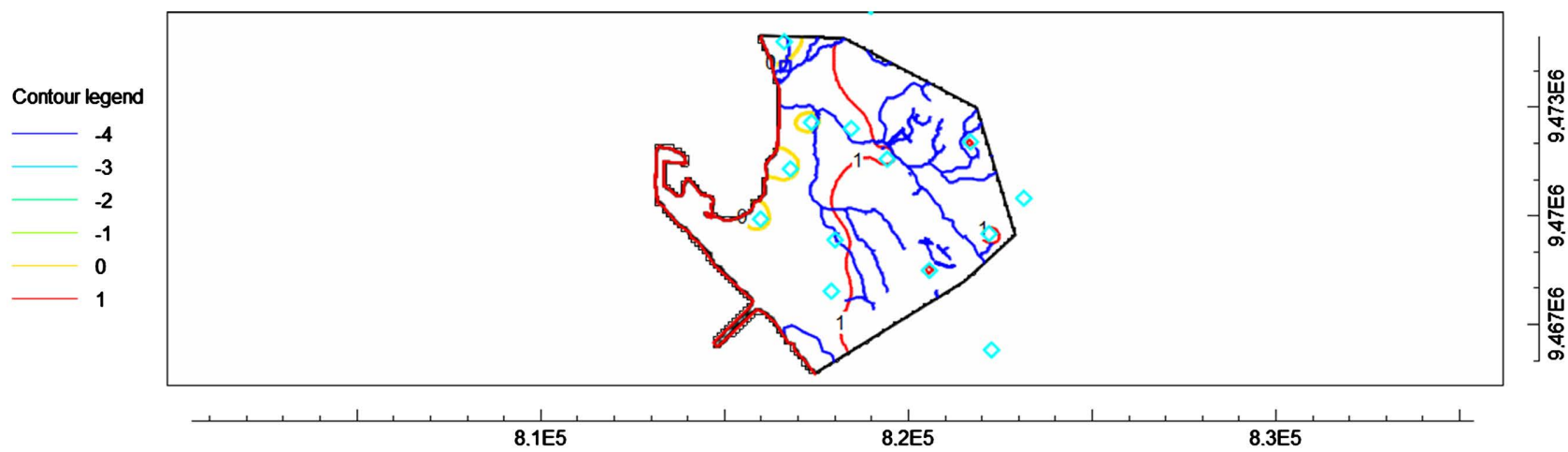

Figure 21. Contour of hydraulic head simulated at 10 years with pumping in steady state and the influence of the climate and others.

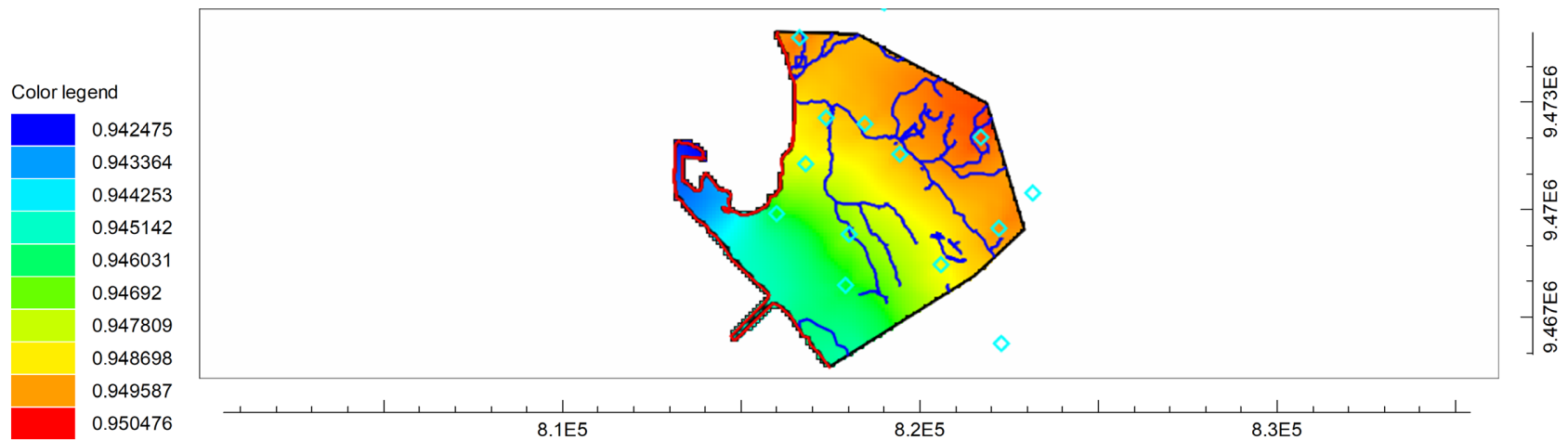

Figure 22. Isosurface of hydraulic head simulated at 25 years with pumping in steady state and the influence of the climate and others.

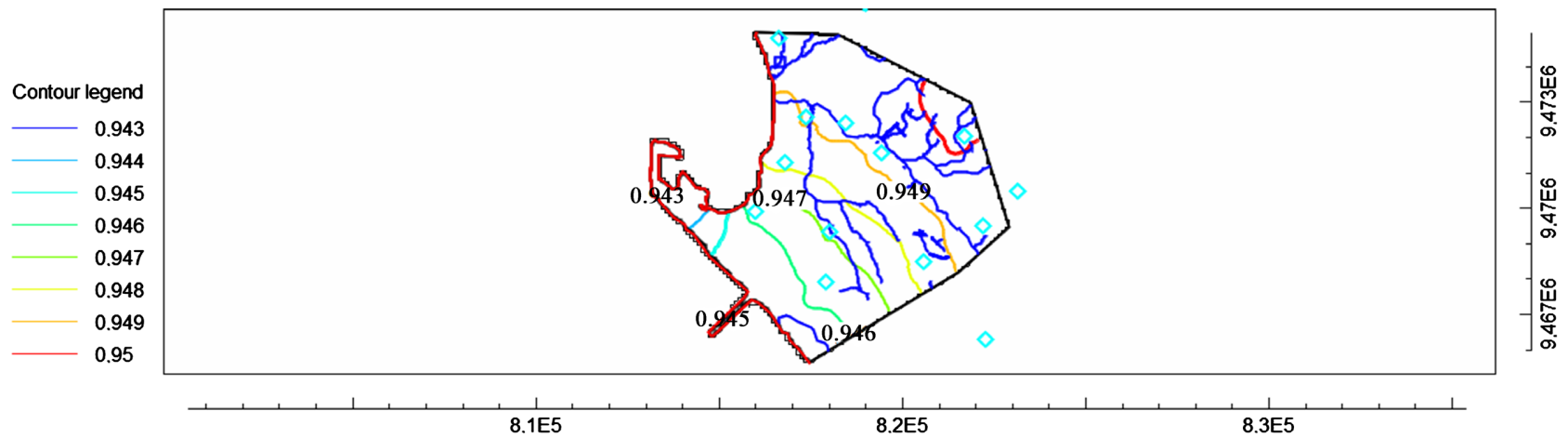

Figure 23. Contour of hydraulic head simulated at 25 years with pumping in steady state and the influence of the climate and others. 


\section{Acknowledgements}

This work was supported by Pan African University Institute for Basic Sciences Technology and Innovation (PAUSTI) for which the authors express their sincere gratitude. Miss Eva HOUESSOU-DOSSOU, we value the help you have given us in carrying out this research.

\section{Conflicts of Interest}

The authors declare no conflicts of interest regarding the publication of this paper.

\section{References}

[1] Moukandi N’Kaya, G.D. (2012) Etude hydrogéologique, hydrochimique in situ et modélisation hydrodynamique du système aquifère du bassin sédimentaire côtier de la région de Pointe-Noire. Thèse de doctorat unique, Université Marien Ngouabi, Faculté des Sciences et Technique, Congo-Brazzaville.

[2] Cabinet, A. and Architecture et Climat, C. (2011) Modélisation des aquifères de la région de Pointe Noire et implantation de nouveaux piézomètres. Rapport No. 01 Données de base et synthèse hydrogéologique.

[3] Cabinet, A. and Architecture et Climat, C. (2012) Synthèse des données piézométriques, hydrochimique et isotopiques Interprétation en termes de modèle conceptuel des écoulements. Rapport No. 02.

[4] Cabinet, A. and Architecture et Climat, C. (2012) Modélisation des aquifères de la région de Pointe Noire et implantation de nouveaux piézomètres. Rapport No. 03 Modélisation numérique.

[5] Moukandi N’Kaya, G.D., Okotaka Ebale, L., Tathy, C., Nzila, J. De D., Mouthou, J.L. and Mabiala, B. (2020) Stratigraphic Data and Groundwater Resources in the Coastal Sedimentary Basin of the Pointe-Noire Region (Republic of Congo). Journal of Water Resource and Protection, 12, 1019-1033.

https://doi.org/10.4236/jwarp.2020.1212061

[6] Moukolo, N. (1992) Etat de connaissances actuelles sur l'hydrogéologie du Congo Brazzaville. Hydrogéologie, 1-2, 47-58.

[7] Moukolo, N. (1984) Ressources en eau souterraine et approvisionnement-Essai d'analyse socio-économique en région équatoriale humide (régions de Brazzaville et Pointe-Noire, Congo). Thèse de doctorat 3 e cycle en géologie appliquée, Université des sciences et techniques du Languedoc.

[8] Tathy, C., Matini, L., N’Kaya, G.M. and Mabiala, B. (2011) Assessing Factors Controlling the Hydrochemistry and Suitability for Irrigation Purposes of Aquifer AQ-2 in Pointe-Noire, South-West Congo-Brazzaville. Research Journal of Applied Sciences, Engineering and Technology, 3, 617-624.

[9] Tathy, C., Matini, L., Mabiala, B., Antoine, F. and Moukandi N’Kaya, G.D. (2010) Hydrochemistry of Groundwater in the Aquifer AQ-2 in Pointe-Noire, South-West Congo-Brazzaville. Research Journal of Applied Sciences, 5, 361-369. https://doi.org/10.3923/rjasci.2010.361.369

[10] Balounta Ngoma, F.B., Tathy, C. and Niece, R.R. (2019) Comparative study of some estimation tropical zone: case of the region of Pointe-Noire (Congo). International Research Journal of Environmental Sciences, 8, 39-52.

[11] Mbilou, U., Tchoumou, M., Ngouala, N. and Balounguidi, J. (2016) hydrogeochem- 
ical and microbiological characterization of ground water in the system of aquifers multi-layer of pointe-noire in Republic of Congo. Larhyss Journal, 28, 257-273.

[12] Tomodiatounga Nkounkou, D., Mabiala, B. and Moukandi N'kaya, G. (2016) Hydrochemical Characteristics of the Groundwater AQ1 of the Region from PointeNoire to Congo Brazzaville. Journal of Geoscience and Environment Protection, 4, 95-109. https://doi.org/10.4236/gep.2016.49008

[13] Winston, R. (2020) Model Muse for Microsoft Windows Operating Systems. https://doi.org/10.5066/P9XMX92F 